\title{
Root Characteristics in Pea in Relation to Compaction and Fusarium Root Rot
}

\author{
John M. Kraft, Research Plant Pathologist (Retired), and W. Boge, Technician, United States Department of \\ Agriculture-Agricultural Research Service, PWA, Prosser, WA 99350
}

\begin{abstract}
Kraft, J. M., and Boge, W. 2001. Root characteristics in pea in relation to compaction and Fusarium root rot. Plant Dis. 85:936-940.

Differences in pea root length, root surface area, and diameter were rapidly determined using the WinRhizo computer program. Repeatable differences were measured both in the laboratory and in the field. Large-rooted lines, as measured in the laboratory, also were the largest-rooted lines in the field. Large-rooted lines produced more roots and had more root surface area when exposed to a $1.6 \mathrm{~g} \mathrm{~cm}^{-3}$ bulk density compacted layer with the presence of the Fusarium root rot pathogen (Fusarium solani f. sp. pisi). Also, large-rooted lines regenerated more roots when one-third or two-thirds of the root system was removed or when one cotyledon was removed from 5-day-old plants. Large-rooted pea lines should have an advantage in growing under adverse conditions of compaction and the presence of Fusarium root rot.
\end{abstract}

Soilborne fungi that cause root rots in pea (Pisum sativum L.), environmental stresses, soil fertility, and soil structural problems are important constraints to increasing or stabilizing yield in the pea crop (1). The principal soilborne rot root pathogens of pea include Aphanomyces euteiches Drechs. and Fusarium solani (Mart.) Sacc. f. sp. pisi (F. R. Jones) W. C. Snyder \& H. N. Hans. (4). Breeding for root rot resistance in pea has been a continuing effort of several state and federal programs since the 1950s (9). Unfortunately, resistance is not governed by major genes but, rather, by what appears to be several minor genes (13). In pea germ plasm enhancement efforts at Prosser, WA, large-rooted pea breeding lines were thought to be more resistant or tolerant to Fusarium root rot. Yield has not always been correlated, however, with large roots in pea. Under low disease pressure and stress, small-rooted lines yield equally with largerooted types.

Roots anchor the plant, absorb and translocate water and nutrients, synthesize and transport growth regulators and other organic compounds, and act as storage organs $(15,16)$. Important characteristics of roots that affect the absorbing surface are length, area, thickness, number of root

Corresponding author: J. M. Kraft

Accepted for publication 10 April 2001.

Publication no. D-2001-0717-05R

This article is in the public domain and not copyrightable. It may be freely reprinted with customary crediting of the source. The American Phytopathological Society, 2001.
E-mail: jmkraft@qwest.net hairs, and mycorhizal associations (16). Even under normal growing conditions, the root environment is seldom ideal for maximum root development. Excess or deficient water, anoxia, high or low soil temperatures, compaction, poor soil fertility, and root pathogens all reduce root growth. Increased soil compaction directly affects root growth rates, root branching patterns, and the number of contacts between the host and root pathogens $(1-3,6)$.

Compaction can drastically restrict root growth and severely limit nutrient availability of major and minor elements with low solubility rates, such as phosphorous (7). Root growth is drastically reduced in compacted soil; therefore, roots cannot grow away from the potential pathogen whose germination is induced by exudates originating from the root tip (6). This is especially true for pea root because $F$. solani f. sp. pisi is a relatively slow colonizer of roots $(6,12)$. Bennie (2) stated that plants with increased rooting ability and small diameter roots have a better chance of finding sites of lower mechanical impedance in compacted soil. In contract to cereal crops, growth of legume roots rate is reported to diminish as seed maturation begins (15). Phenotypic differences in length and area of root systems has been reported for a number of legumes, but not for pea (18).

This study was conducted to determine rooting vigor in pea by measuring total plant root area produced over time in commercial cultivars, Agricultural Research Service pea breeding lines, and in the Plant Introduction (PI) accession 180693 (9). We also investigated whether increased root length and increased root surface area reduced the negative effects of growing in compacted soil and the severity of root infection by $F$. solani f. sp. pisi. Differences in root regeneration and root growth of seedlings after removal of cotyledons also was examined.

\section{MATERIALS AND METHODS}

Pea lines. The pea lines evaluated in this study, along with the seed source, rooting characteristics, and reaction to Fusarium root rot, are listed in Table 1. Seed was stored at 7 to $10^{\circ} \mathrm{C}$ until used and was treated with Captan only when planted in the field. Large-rooted, medium-rooted, and small-rooted lines produced an average of continues beyond flowering, although the

Table 1. Pea lines, seed source, and rooting characteristics

\begin{tabular}{llll}
\hline Pea line $^{\mathbf{x}}$ & \multicolumn{1}{c}{ Source } & Root type $^{\mathbf{y}}$ & Fusarium resistance $^{\mathbf{z}}$ \\
\hline PI 180693 & Plant Introduction, Pullman, WA & Large & Partially resistant \\
$93-2088$ & J. M. Kraft & Large & Susceptible \\
93-2098 & J. M. Kraft & Large & Resistant \\
93-2144 & J. M. Kraft & Large & Resistant \\
$97-2170$ & J. M. Kraft & Medium & Resistant \\
$97-2058$ & J. M. Kraft & Medium & Resistant \\
$96-2198$ & J. M. Kraft & Medium & Partially resistant \\
Bolero & Seminus Seeds, Inc. & Medium & Susceptible \\
Dark Skin Perfection & Pure Line Seeds, Inc. & Medium & Partially resistant \\
FR-100-1 & Pure Line Seeds, Inc. & Small & Susceptible \\
FR-244-1 & Pure Line Seeds, Inc. & Small & Susceptible \\
FR-93 & Pure Line Seeds, Inc. & Small & Susceptible \\
\hline
\end{tabular}

${ }^{x} \mathrm{PI}=$ Plant Introduction accession.

${ }^{y}$ Large-rooted lines produced 250 to 350 , medium-rooted lines produced 180 to 220 , and smallrooted lines produced 90 to $110 \mathrm{~cm}$ of root after a 14-day incubation period.

${ }^{\mathrm{z}}$ Fusarium root rot reaction on a 0 -to- 5 scale where $0=$ healthy root and $5=$ completely rooted root; resistant $=0$ to 2.0 , partially resistant $=2.5$ to 3.5 , and susceptible $=3.5$ to 5.0 . 
250 to 350,180 to 220 , and 90 to $110 \mathrm{~cm}$ of root, respectively, after a 14-day incubation.

Root scans and analysis. A Hewlett Packard 4C scanner fitted with a transparency adapter and calibrated by Regent Instruments, Inc. was used to scan pea roots. Each root was arranged on the scanner bed so that there was as much separation as possible between secondary roots with a minimum of overlap. After each root scan, the image was analyzed for length, area, and volume. The WinRhizo program (v. 3.8; Regent Instruments, Inc., Quebec, Canada) was used to analyze root data on a Gateway 2000 E-311D-266 mhz computer (Gateway, Inc., N. Sioux City, SD) with an 8.4 GB hard drive and $64 \mathrm{MB}$ of RAM storage.

Field studies. PI 180693 and a largerooted pea breeding line (97-2170), four medium-rooted lines (96-2058, 96-2198, and commercial cvs. Bolero and Dark Skin Perfection), and three small-rooted lines (Fr-100-1, FR-244-1, and FR-93) were germinated in the dark on germination paper in an incubator set at a constant $20^{\circ} \mathrm{C}$. Five-day-old seedlings were planted into 61-by-15-cm diameter PVC tubes that were split in half and joined together with duct tape. The field soil used for this test was screened through a $0.6-\mathrm{cm}$ mesh screen to remove excess debris and rocks. Each tube was filled with approximately the same amount of soil by shaking the tube as it was filled to $1 \mathrm{~cm}$ from the top; it was shaken during filling to approximate a $1.3 \mathrm{~g} \mathrm{~cm}^{-3}$ bulk density (3).

The soil type was a Moxee silt loam (39\% sand, $57 \%$ silt, and $3.6 \%$ clay), $\mathrm{pH}$
6.9. The organic matter was approximately $0.5 \%$. The inoculum level of $F$. solani f. sp. pisi and Pythium spp. was approximately 550 and $250 \mathrm{CFU} / \mathrm{gm}$ of air-dried soil, respectively, as determined by soil dilution assays (11). A. euteiches was not present in this soil as determined by the wet-sieve procedure (10).

A $25-\mathrm{cm}$-diameter post hole digger was used to create a hole for each tube. Each pea line was planted into 24 tubes with four seeds per tube and thinned to one plant upon emergence. Plants were harvested at 4 weeks after emergence, full bloom, and full maturity. Six tubes for each line were harvested at each harvest date. The PVC tubes were watered by overhead sprinkle irrigation on a weekly basis so that $2.5 \mathrm{~cm}$ of water was applied in an 8-h set each week. The experimental design was a randomized complete block with six replications per harvest date per pea line.

At each harvest, tubes containing test plants were removed from the field and transported to a washing facility, and soil was carefully removed from each root system with pressurized water. Harvested and prepared roots were first read for root rot severity using a 0 -to- 5 scale where $0=$ a healthy root and $5=$ a completely rotted root (9). Processed roots then were placed between moistened paper towels and stored at $4{ }^{\circ} \mathrm{C}$ until measured for fresh top weight and tap root length. Each root was analyzed using the WinRhizo computerscanning program for total length, surface area, and average diameter.

Root regeneration test. The ability of the same nine pea germ plasm lines and cultivars to regenerate roots was studied in the laboratory. Fifty seeds of each test line were surface disinfected (8) and placed on germination paper in an incubation chamber set at $25^{\circ} \mathrm{C}$ with a 16 -h day and 400 lux of illumination. Five days after germination, the best 36 (longest rooted) seedlings were removed and none, one-third, or two-thirds of the tap root from each plant was aseptically excised. The treated seedlings were placed back onto germination paper and incubated for another 9 days. The germination paper sandwich was layered for each test line and placed vertically in a Tupperware container ( 30.5 by 15.2 by $10.2 \mathrm{~cm}$ ) and the bottom was covered with a $0.5 \times$ Hogland's solution to keep the germination paper wet and supply the test seedlings with nutrients necessary for growth.

All plants were 14 days old when harvested and analyzed. The plant shoot and cotyledons were excised and the seedling root was rolled in a moistened paper towel and stored at $4^{\circ} \mathrm{C}$ until scanned. There were 10 replications per excision length for each cultivar; the test was repeated and the experiment was set up as a randomized block design. Because of the large number of roots to be scanned, this study was designed as two separate tests with one-third of the tap root removed as one test and two-thirds of the tap root removed as a second test.

Root growth as affected by cotyledon removal. Seedlings of the nine pea lines were placed on germination paper and, after a 5-day incubation, those with the longest roots $(>10-\mathrm{cm}$-long tap root) were

Table 2. Rooting characteristics of nine pea lines under field conditions

\begin{tabular}{|c|c|c|c|c|c|c|c|c|c|c|c|c|c|c|c|c|}
\hline \multirow[b]{2}{*}{ Pea line } & \multirow[b]{2}{*}{$\begin{array}{l}\text { Root } \\
\text { type }\end{array}$} & \multicolumn{3}{|c|}{$\begin{array}{c}\text { Tap root length } \mathrm{cm} / \\
\text { plant }\end{array}$} & \multicolumn{3}{|c|}{$\begin{array}{c}\text { Fresh root weight gm/ } \\
\text { plant }\end{array}$} & \multicolumn{3}{|c|}{$\begin{array}{c}\text { Total root length } \mathrm{cm} / \\
\text { plant }\end{array}$} & \multicolumn{3}{|c|}{$\begin{array}{c}\text { Surface area } \mathrm{cm}^{3} / \\
\text { plant }\end{array}$} & \multicolumn{3}{|c|}{$\begin{array}{l}\text { Root diameter avg. cm/ } \\
\text { root system }\end{array}$} \\
\hline & & $\begin{array}{c}4 \\
\text { weeks }\end{array}$ & Bloom & $\begin{array}{l}\text { Full } \\
\text { pod }\end{array}$ & $\begin{array}{c}4 \\
\text { weeks }\end{array}$ & Bloom & $\begin{array}{l}\text { Full } \\
\text { pod }\end{array}$ & $\begin{array}{c}4 \\
\text { weeks }\end{array}$ & Bloom & $\begin{array}{l}\text { Full } \\
\text { pod }\end{array}$ & $\begin{array}{c}4 \\
\text { weeks }\end{array}$ & Bloom & $\begin{array}{l}\text { Full } \\
\text { pod }\end{array}$ & $\begin{array}{c}4 \\
\text { weeks }\end{array}$ & Bloom & $\begin{array}{l}\text { Full } \\
\text { pod }\end{array}$ \\
\hline PI-180693 & Large & $37.4 \mathrm{bc}$ & $41.5 \mathrm{~cd}$ & $43.7 \mathrm{bc}$ & $5.74 \mathrm{a}$ & $7.88 \mathrm{a}$ & $8.70 \mathrm{a}$ & $5,093 \mathrm{ab}$ & 6,476 a & $9,581 \mathrm{a}$ & $818.5 \mathrm{ab}$ & $819.0 \mathrm{a}$ & $864.8 \mathrm{a}$ & $0.052 \mathrm{~b}$ & $0.047 \mathrm{a}$ & $0.029 \mathrm{bc}$ \\
\hline $97-2170$ & Large & $46.8 \mathrm{a}$ & $44.8 \mathrm{bc}$ & $51.4 \mathrm{ab}$ & $5.77 \mathrm{a}$ & $5.66 \mathrm{bc}$ & $6.91 \mathrm{~b}$ & $5,759 \mathrm{a}$ & $5,799 \mathrm{ab}$ & $7,278 \mathrm{~b}$ & $900.0 \mathrm{a}$ & $726.7 \mathrm{ab}$ & $673.8 \mathrm{~b}$ & $0.056 \mathrm{a}$ & $0.042 \mathrm{bc}$ & $0.030 \mathrm{bc}$ \\
\hline $96-2058$ & Large & $45.0 \mathrm{a}$ & $54.8 \mathrm{a}$ & $51.5 \mathrm{ab}$ & $4.76 \mathrm{ab}$ & $4.16 \mathrm{~cd}$ & $5.32 \mathrm{bd}$ & $3,694 \mathrm{bd}$ & $4,685 \mathrm{bc}$ & 5,183 ce & $626.7 \mathrm{~cd}$ & $620.8 \mathrm{bc}$ & $497.5 \mathrm{c}$ & $0.056 \mathrm{a}$ & $0.044 \mathrm{ab}$ & $0.031 \mathrm{ac}$ \\
\hline $96-2198$ & Medium & $35.6 \mathrm{bc}$ & $36.4 \mathrm{~d}$ & $43.9 \mathrm{bc}$ & $4.67 \mathrm{ab}$ & $6.27 \mathrm{~b}$ & $5.71 \mathrm{bc}$ & $4,420 \mathrm{ac}$ & $6,224 \mathrm{a}$ & $6,170 \mathrm{bc}$ & $673.5 \mathrm{bd}$ & $755.7 \mathrm{ab}$ & $547.2 \mathrm{bc}$ & $0.051 \mathrm{~b}$ & $0.041 \mathrm{c}$ & $0.029 \mathrm{bc}$ \\
\hline \multicolumn{16}{|c|}{ Perfection } & $0.030 \mathrm{bc}$ \\
\hline Bolero & Medium & $42.5 \mathrm{ab}$ & $40.8 \mathrm{~cd}$ & $44.4 \mathrm{bc}$ & $3.89 \mathrm{bc}$ & $4.01 \mathrm{~cd}$ & $3.47 \mathrm{e}$ & $3,341 \mathrm{~cd}$ & $3,634 \mathrm{~cd}$ & $4,388 \mathrm{df}$ & $528.8 \mathrm{de}$ & $465.7 \mathrm{~cd}$ & $533.3 \mathrm{bc}$ & $0.052 \mathrm{~b}$ & $0.041 \mathrm{c}$ & $0.030 \mathrm{bc}$ \\
\hline FR-93 & Small & $35.6 \mathrm{bc}$ & $49.3 \mathrm{ab}$ & $52.9 \mathrm{a}$ & $2.54 \mathrm{c}$ & $3.81 \mathrm{~d}$ & 4.01 ce & $2,538 \mathrm{de}$ & $3,578 \mathrm{~cd}$ & $4,666 \mathrm{df}$ & $396.5 \mathrm{ef}$ & $450.0 \mathrm{~cd}$ & $415.3 \mathrm{c}$ & $0.051 \mathrm{~b}$ & $0.039 \mathrm{c}$ & $0.029 \mathrm{c}$ \\
\hline FR-100-1 & Small & $33.1 \mathrm{c}$ & $40.6 \mathrm{~cd}$ & $46.8 \mathrm{ac}$ & $2.81 \mathrm{c}$ & $4.19 \mathrm{~cd}$ & $3.82 \mathrm{de}$ & $2,333 \mathrm{de}$ & $3,305 \mathrm{~cd}$ & $3,641 \mathrm{f}$ & $420.3 \mathrm{ef}$ & $443.7 \mathrm{~cd}$ & $378.0 \mathrm{c}$ & $0.058 \mathrm{a}$ & $0.040 \mathrm{c}$ & $0.034 \mathrm{a}$ \\
\hline \multirow[t]{2}{*}{ FR-244-1 } & Small & $35.0 \mathrm{bc}$ & $33.9 \mathrm{~d}$ & $41.4 \mathrm{c}$ & $2.24 \mathrm{c}$ & $2.93 \mathrm{~d}$ & $3.54 \mathrm{e}$ & $1,814 \mathrm{e}$ & $2,367 \mathrm{~d}$ & 3,804 ef & $287.3 \mathrm{f}$ & $346.5 \mathrm{~d}$ & $377.3 \mathrm{c}$ & $0.050 \mathrm{~b}$ & $0.040 \mathrm{c}$ & $0.032 \mathrm{ab}$ \\
\hline & & \multicolumn{3}{|c|}{$\mathrm{LSD}=6.97$} & \multicolumn{3}{|c|}{$\mathrm{LSD}=1.60$} & \multicolumn{3}{|c|}{$\mathrm{LSD}=1339$} & \multicolumn{3}{|c|}{$\mathrm{LSD}=175.1$} & \multicolumn{3}{|c|}{$\mathrm{LSD}=0.003$} \\
\hline
\end{tabular}

Table 3. Analysis of variance: field study

\begin{tabular}{|c|c|c|c|c|c|c|c|c|c|c|c|c|c|}
\hline \multirow[b]{2}{*}{ Source } & \multirow[b]{2}{*}{ df } & \multicolumn{3}{|c|}{ Total root length } & \multicolumn{3}{|c|}{ Root disease severity } & \multicolumn{3}{|c|}{ Tap root length } & \multicolumn{3}{|c|}{ Root surface area } \\
\hline & & $\begin{array}{l}\text { Sum of } \\
\text { squares }\end{array}$ & $\begin{array}{l}\text { Mn. sq. } F \\
\text { value }\end{array}$ & f value & $\begin{array}{l}\text { Sum of } \\
\text { squares }\end{array}$ & $\begin{array}{l}\text { Mn. sq. } \\
F \text { value }\end{array}$ & f value & $\begin{array}{l}\text { Sum of } \\
\text { squares }\end{array}$ & $\begin{array}{l}\text { Mn. sq. } \\
F \text { value }\end{array}$ & f value & $\begin{array}{l}\text { Sum of } \\
\text { squares }\end{array}$ & $\begin{array}{l}\text { Mn. sq. } \\
F \text { value }\end{array}$ & f value \\
\hline Replication & 5 & $4,197,434.42$ & $839,486.88$ & 0.3446 & 0.519 & 0.104 & 0.3218 & $1,314.56$ & 262.9 & 3.0105 & $70,382.94$ & $14,076.59$ & 0.3835 \\
\hline Harvest date & 2 & $92,432,655.35$ & $46,216,327.67$ & $18.9709^{*}$ & 10.259 & 5.130 & $15.9195^{*}$ & $1,496.79$ & 748.4 & $8.5825^{*}$ & $188,304.10$ & $94,152.04$ & $2.5648 *$ \\
\hline Cultivars & 8 & $31,753,839.35$ & $39,692,294.92$ & $28.9442 *$ & 1.444 & 0.181 & 0.9315 & $2,845.89$ & 355.7 & $9.5728^{*}$ & $4,142,915.00$ & $517,864.37$ & $22.0816^{*}$ \\
\hline $\begin{array}{l}\text { Cultivar } \times \\
\text { harvest date }\end{array}$ & 16 & $42,339,336.10$ & $2,646,208.51$ & 1.9297 & 3.296 & 0.206 & 1.0629 & $1,150.40$ & 71.9 & 1.9348 & $2,814,277.26$ & $33,622.30$ & 1.4336 \\
\hline \multirow[t]{2}{*}{ Error } & 120 & $164,560,532.00$ & $1,371,337.00$ & & 23.300 & 0.190 & & $4,459.30$ & 37.2 & & $2,814,277.00$ & $23,452.30$ & \\
\hline & & \multicolumn{3}{|l|}{$\begin{array}{l}\text { Coefficient of } \\
\text { variation } 25.39 \%\end{array}$} & \multicolumn{3}{|c|}{$\begin{array}{l}\text { Coefficient of } \\
\text { variation } 11.65 \%\end{array}$} & \multicolumn{3}{|c|}{$\begin{array}{l}\text { Coefficient of } \\
\text { variation } 14.27 \%\end{array}$} & \multicolumn{2}{|c|}{$\begin{array}{l}\text { Coefficient of } \\
\text { variation } 27.08 \%\end{array}$} & \\
\hline
\end{tabular}


selected. Treatments included removing one or both cotyledon halves and leaving control plants with cotyledons intact. Both described previously. Twelve seedlings were replicated twice for each test line. After a 14-day incubation period, the 10 most representative for each line were selected for a root scan. Seedling shoots were excised just above the cotyledonary attachment area prior to scanning.

Soil compaction-Fusarium test. The effect of soil compaction and Fusarium root rot on root growth of a large-rooted line (93-2144, susceptible to Fusarium root rot) and a medium-rooted line (93-2098, resistant to Fusarium root rot) was studied in a controlled environment cabinet set at $24^{\circ} \mathrm{C}$ day and $18^{\circ} \mathrm{C}$ night and a 16 -h photoperiod with illumination of approximately $320 \mathrm{lum} / \mathrm{m}$.

Individual plants were grown in 30-by15-cm PVC tubes cut into three layers. The top layer was $13 \mathrm{~cm}$ deep and was considered noncompacted $\left(1.1 \mathrm{~g} \mathrm{~cm}^{-3}\right)$. The middle layer contained a compacted $\left(1.6 \mathrm{~g} \mathrm{~cm}^{-3}\right)$ or noncompacted $\left(1.1 \mathrm{~g} \mathrm{~cm}^{-3}\right)$ soil layer and was $5 \mathrm{~cm}$ deep. The $1.6 \mathrm{~g} \mathrm{~cm}^{-3}$ bulk density approximated a compacted plow sole under field conditions (3). An aluminum foil ring was placed on top of the bulk density layer to force growing roots to grow through the compacted layer and not down the container sides. The bottom layer was $12 \mathrm{~cm}$ in depth and was also at $1.1 \mathrm{~g}$ $\mathrm{cm}^{-3}$ bulk density. These three layers were stacked one on top of the other and secured in place with duct tape.

The same Moxee silt loam soil described above was collected from a site which had not been cropped to pea and autoclaved to root pathogens. A portion of the autoclaved soil was infested with a conidial suspension of $F$. solani f. sp. pisi and air dried to induce chlamydospore formation (11). This stock soil was diluted with autoclaved soil to develop a test soil containing $F$. solani f. sp. pisi at approximately 5,000 CFU/g. Both infested and noninfested soils were air dried and then adjusted to $17 \%$ control and test plants were incubated as eliminate any potential fungal or nematode

soil moisture (11). Each tube was covered, top and bottom, with 3-mil plastic to reduce water evaporation prior to planting.

Each tube was planted with six seeds of either line and thinned to four plants per tube after emergence. Treatments consisted of planting each line in tubes with (i) no Fusarium conidia and no compaction, (ii) no Fusarium-infested soil in the top layer and the middle layer compacted to $1.6 \mathrm{~cm}^{-3}$, (iii) Fusarium-infested top layer and no compaction, and (iv) Fusarium-infested top layer and a compacted middle layer. $F$. solani f. sp. pisi was not present in the bottom layer of any treatment.

At the start of the experiment, all tubes were watered to $22 \%$ gravimetric soil moisture. Each tube was allowed to dry down to a $17 \%$ soil moisture level, based on predetermined weights of each tube, before rewatering up to the $22 \%$ level using deionized water. The experiment was harvested when each plant had at least one flower per plant. Roots were carefully washed to remove attached soil, assessed for disease severity (0-to-5 scale), wrapped in moistened paper towels, and stored at $4^{\circ} \mathrm{C}$ until analyzed. Tops were excised directly above the cotyledonary attachment area and fresh weights of tops and roots were determined. Roots from each replicate were analyzed with the WinRhizo program. There were six replications per treatment and the experiment was repeated. Data were analyzed as a complete block design. A homogeneity of variance test was performed and the differences between tests were minimal, allowing for combined analysis of both tests.

\section{RESULTS}

Field studies. The objective was to determine if differences in root vigor measured in the laboratory correlated with field measurements. The smaller-rooted lines (FR-100-1, FR-244-1, and FR-93) also were small rooted under field conditions (Table 2). The large- and medium-rooted lines expressed nonsignificant differences in root length or area under field conditions. Root growth continued when plants

Table 4. Effect of tap root removal on root regrowth

\begin{tabular}{|c|c|c|c|c|c|}
\hline \multirow[b]{3}{*}{ Pea line } & \multirow[b]{3}{*}{ Root type } & \multicolumn{4}{|c|}{ Root length $(\mathrm{cm})^{\mathrm{y}}$} \\
\hline & & \multicolumn{2}{|c|}{ One-third root } & \multicolumn{2}{|c|}{ Two-thirds root } \\
\hline & & Control & Excised & Control & Excised \\
\hline PI 180693 & Large & $454.0 \mathrm{a}$ & $440.5 \mathrm{a}$ & $509.6 \mathrm{a}$ & $359.1 \mathrm{~b}$ \\
\hline $96-2058$ & Large & $343.5 \mathrm{~b}$ & $307.0 \mathrm{c}$ & $396.5 \mathrm{~b}$ & $266.9 \mathrm{~cd}$ \\
\hline $97-2170$ & Large & $280.1 \mathrm{~cd}$ & $302.1 \mathrm{c}$ & $377.5 \mathrm{~b}$ & $232.5 \mathrm{de}$ \\
\hline $96-2198$ & Medium & 219.2 ef & $251.6 \mathrm{de}$ & $276.2 \mathrm{c}$ & $187.2 \mathrm{f}$ \\
\hline Bolero & Medium & $192.5 \mathrm{fg}$ & 218.7 ef & $213.6 \mathrm{ef}$ & $178.1 \mathrm{fg}$ \\
\hline Dark Skin Perfection & Medium & $176.1 \mathrm{gh}$ & $201.6 \mathrm{fg}$ & $238.3 \mathrm{ce}$ & $183.1 \mathrm{fg}$ \\
\hline FR-93 & Small & $148.9 \mathrm{hj}$ & $156.1 \mathrm{hi}$ & $112.9 \mathrm{~h}$ & $125.9 \mathrm{~h}$ \\
\hline FR-100-1 & Small & $132.5 \mathrm{ij}$ & $131.1 \mathrm{ij}$ & $143.0 \mathrm{gh}$ & $129.3 \mathrm{~h}$ \\
\hline FR-244-1 & Small & $117.5 \mathrm{j}$ & $113.8 \mathrm{j}$ & $141.4 \mathrm{gh}$ & $120.8 \mathrm{~h}$ \\
\hline $\mathrm{LSD}^{\mathrm{z}}$ & $\ldots$ & 29.53 & $\ldots$ & 37.11 & $\ldots$ \\
\hline
\end{tabular}

${ }^{\mathrm{y}}$ Means within a given test and column followed by the same letter are not significantly different at $P=0.05$.

${ }^{\mathrm{z}} \mathrm{LSD}=$ least significant difference. initiated flowers or when plants possessed fully mature pods (Table 2). Fusarium root rot was uniform across all treatments and was more severe at the mature pod stage. There was a significant $F$ value $(P=0.05)$ for root disease severity readings and harvest date (Table 3), indicating that roots exposed to this pathogen for an extended period were more severely diseased. There were no differences in root rot severity between lines (Table 3). Lines that were classified as having large roots under laboratory conditions had significantly more root area at the end of the experiment than those with small roots (Table 2).

No positive relationship was detected between total root length and tap root length. In fact, some of the smaller-rooted lines had tap roots as long as those possessed by larger-rooted lines (Table 2). Average root diameter decreased with age across all lines (Table 2). This was most likely due to numbers of smaller roots produced as root length increased with age. Root weight increased with all lines but decreased with Bolero, which is highly susceptible to Fusarium root rot (Table 2). Lines with some resistance or tolerance to Fusarium root rot (i.e., PI 180693, 962170, 96-2198, 96-2058, and Dark Skin Perfection) and possessing medium or large roots increased more total root weight with age in contrast to those lines which were susceptible and smaller rooted (i.e., Bolero, FR-93, FR-100-1, and FR244-1).

Analysis of variance revealed significant differences among pea lines and harvest dates for root length, tap root length, and root surface area but not for root disease severity (Table 3). The coefficient of variation varied between 11.7 and $27.1 \%$ for the parameters.

Root regrowth experiments. When one-third of the initial root system was excised, differences in root length were essentially the same between the control plants and the treatments (Table 4). When two-thirds of the root system was removed, there was a significant decrease in root length as compared to the control plants for five of nine pea lines. However, the order of large- to small-rooted lines remained essentially the same.

Effect of cotyledon removal on root growth. The removal of one cotyledon reduced root length by 38 to $68 \%$ (Table 5). The large-rooted lines (PI 180693 and 96-2170) and the medium-rooted 96-2058 had a greater capacity to regrow roots than the small-rooted lines (Table 5). The removal of both cotyledons resulted in essentially no further root growth, and losses ranged from 91 to $97 \%$. Differences in loss of root surface area were essentially related to the root length of the control plants (Table 5). The large- or mediumrooted lines (180693, 96-2068, 96-2170, 96-2198, Dark Skin Perfection, and Bolero) produced significantly more root 
surface area than the smaller-rooted lines (FR-244-1, Fr-100-1, and FR-93) when one cotyledon was removed (Table 5).

Fusarium and compaction study. The large-rooted line (93-2144) had more total root length than the medium-rooted line (93-2098) without compaction and without F. solani f. sp. pisi (Table 6). The loss in root length when roots were exposed to a compaction and $F$. solani f. sp. pisi layer was twice as much for the large-rooted line, which was susceptible to Fusarium root rot, as compared with the mediumrooted line, which was resistant. In addition, when both lines were exposed to a compaction layer, minus $F$. solani f. sp. pisi, the loss in root length was greater than when either pea line was exposed to $F$. solani f. sp. pisi alone.

\section{DISCUSSION}

This research has determined that the amount of root growth over time varies significantly among pea cultivars and breeding lines and that there are advantages for a pea plant to possess a large root system. There appeared to be a decided advantage to larger roots when the relative growth of pea roots was assessed following cotyledon removal or root excision. Those lines with more vigorous root systems produced more roots after one cotyledon was removed or when the roots were pruned. Our findings corroborate previous work (15) where one or both cotyledons were excised, resulting in a $50 \%$ reduction in the number of lateral roots with the removal of one cotyledon. Total cotyledon removal reduced the number of laterals to essentially zero for any line tested. In a study not reported here, we measured root growth of a number of pea cultivars, breeding lines, and PI accessions (unpublished data). We found that root growth was directly related to seed size. This substantiates earlier work (15) that demonstrated the importance of cotyledons in supplying the growth regulators required for tap, secondary, and tertiary root growth.

Heyes (5) stated that the rate of root growth varies among pea cultivars. Use of this scanning program allowed us to quantify root growth differences among pea lines and show the relative advantages of pea lines which produce large amounts of roots per unit of time. This scanning program also allowed us to measure a large number of roots quickly. As compared with the root-line intercept procedure of Ward et al. (17), the root scanning procedure was a significant improvement in measuring root characteristics. Data on total root length, root surface area, root diameter, and root branching could all be collected from one scan. Taylor and Gardner (14) could not find differences between the ability of legumes and non-legumes to penetrate compacted layers. Bennie (2) stated that the relative decrease in root length, rooting density, or number of roots entering a compacted layer is the same for most plant species. He further stated that the differences observed were related to their genetic potential to produce roots in non- compacted soil. Plants with many fine roots are thought to have a higher probability of finding sites of lower mechanical impedance (14). This research reconfirms that differences in rooting ability differentiated in axenic culture is comparable to differences measured in the field.

Pea lines classified as large, medium, or small rooted when grown in a growth cabinet, on germination paper, were essentially the same when grown in PVC pipe under field conditions. This finding should allow pea breeders to screen and identify pea germ plasm for increased root growth in the greenhouse or laboratory. Destructive sampling can be avoided and strong-rooted segregants within a breeding line can be identified and saved for seed. This would be quite difficult under field conditions.

Kraft and Wilkins (12) demonstrated the importance of unrestricted root growth in reducing the effects of Fusarium root rot on pea. This same relationship holds true when comparing a large-rooted line to a medium-rooted line in Fusarium-infested soil. This was evident from the soil compaction-Fusarium root rot interaction study. The larger-rooted line had significantly more roots after being exposed to both compaction and $F$. solani f. sp. pisi than did the smaller-rooted line. However, reduction in root growth for the largerrooted line was more than for the smallerrooted line. Compaction alone reduced root growth more than $F$. solani $\mathrm{f}$. sp. pisi alone for both lines.

Table 5. Effect of cotyledon removal on root length and surface area ${ }^{y}$

\begin{tabular}{|c|c|c|c|c|c|c|c|c|c|c|c|}
\hline \multirow[b]{3}{*}{ Pea line ${ }^{z}$} & \multirow[b]{3}{*}{ Root type } & \multicolumn{5}{|c|}{ Root length (cm) } & \multicolumn{5}{|c|}{ Root surface area $(\mathrm{cm})^{3}$} \\
\hline & & \multicolumn{2}{|c|}{ Half cotyledon } & \multicolumn{2}{|c|}{ Whole cotyledon } & \multirow{2}{*}{$\frac{\text { Control }}{\text { Length }}$} & \multicolumn{2}{|c|}{ Half cotyledon } & \multicolumn{2}{|c|}{ Whole cotyledon } & \multirow{2}{*}{$\frac{\text { Control }}{\text { Area }}$} \\
\hline & & Length & $\%$ Loss & Length & $\%$ Loss & & Area & $\%$ Loss & Area & $\%$ Loss & \\
\hline 180693 & Large & $197.3 \mathrm{a}$ & $41.9 \mathrm{ab}$ & $9.75 \mathrm{bc}$ & $97.1 \mathrm{e}$ & $340.0 \mathrm{a}$ & $27.62 \mathrm{~b}$ & $40.1 \mathrm{ab}$ & $3.64 \mathrm{~b}$ & $92.2 \mathrm{~d}$ & $46.72 \mathrm{~b}$ \\
\hline $96-2058$ & Large & $206.2 \mathrm{a}$ & $37.9 \mathrm{a}$ & $12.98 \mathrm{a}$ & $96.1 \mathrm{de}$ & $332.0 \mathrm{a}$ & $32.54 \mathrm{a}$ & $39.0 \mathrm{a}$ & $4.43 \mathrm{a}$ & $91.7 \mathrm{~cd}$ & $53.35 \mathrm{a}$ \\
\hline $97-2170$ & Large & $147.6 \mathrm{~b}$ & $42.8 \mathrm{ab}$ & $8.10 \mathrm{de}$ & $96.9 \mathrm{e}$ & $258.0 \mathrm{~b}$ & $24.58 \mathrm{c}$ & $46.0 \mathrm{bc}$ & $3.40 \mathrm{bc}$ & $92.5 \mathrm{~d}$ & $45.52 \mathrm{~b}$ \\
\hline $96-2198$ & Medium & $117.8 \mathrm{c}$ & $46.1 \mathrm{bd}$ & $10.80 \mathrm{~b}$ & $95.1 \mathrm{~cd}$ & $218.5 \mathrm{c}$ & $20.83 \mathrm{~d}$ & $45.8 \mathrm{~b}$ & $3.61 \mathrm{~b}$ & $90.6 \mathrm{c}$ & $38.44 \mathrm{c}$ \\
\hline Dk. Skin Perf. & Medium & $103.3 \mathrm{c}$ & $51.8 \mathrm{~cd}$ & $9.40 \mathrm{~cd}$ & $95.6 \mathrm{~cd}$ & $214.4 \mathrm{c}$ & $21.20 \mathrm{~d}$ & $44.1 \mathrm{ab}$ & $3.21 \mathrm{c}$ & $91.5 \mathrm{~cd}$ & $37.95 \mathrm{c}$ \\
\hline Bolero & Medium & $81.8 \mathrm{~d}$ & $57.6 \mathrm{~d}$ & $10.26 \mathrm{bc}$ & $94.6 \mathrm{c}$ & $193.1 \mathrm{c}$ & $15.85 \mathrm{e}$ & $52.1 \mathrm{~cd}$ & $3.61 \mathrm{~b}$ & $89.1 \mathrm{~b}$ & $33.07 \mathrm{~d}$ \\
\hline FR-244-1 & Small & $52.1 \mathrm{e}$ & $52.8 \mathrm{~cd}$ & $7.96 \mathrm{e}$ & $92.7 \mathrm{~b}$ & $110.5 \mathrm{~d}$ & $11.46 \mathrm{f}$ & $45.2 \mathrm{ab}$ & $2.38 \mathrm{e}$ & $88.6 \mathrm{~b}$ & $20.90 \mathrm{e}$ \\
\hline FR-100-1 & Small & $46.9 \mathrm{ef}$ & $54.4 \mathrm{~d}$ & $9.40 \mathrm{~cd}$ & $90.9 \mathrm{a}$ & $102.8 \mathrm{~d}$ & $10.68 \mathrm{f}$ & $45.9 \mathrm{bc}$ & $2.84 \mathrm{~d}$ & $85.6 \mathrm{a}$ & $19.75 \mathrm{e}$ \\
\hline FR-93 & Small & $31.5 \mathrm{f}$ & $68.4 \mathrm{e}$ & $9.49 \mathrm{bc}$ & $90.5 \mathrm{a}$ & $99.4 \mathrm{~d}$ & $8.23 \mathrm{~g}$ & $55.8 \mathrm{~d}$ & $2.75 \mathrm{~d}$ & $85.2 \mathrm{a}$ & $18.64 \mathrm{e}$ \\
\hline LSD & $\ldots$ & 16.7 & 7.7 & 1.3 & 1.1 & 26.4 & 2.4 & 6.2 & 0.3 & 1.3 & 4.4 \\
\hline
\end{tabular}

${ }^{\mathrm{y}}$ Means followed by the same letter or letters are not significant at $P=0.05$.

${ }^{\mathrm{z}}$ Dk. Skin Perf. $=$ cv. Dark Skin Perfection; LSD = least significant difference.

Table 6. Effect of compaction and Fusarium solani f. sp. pisi on root growth ${ }^{y}$

\begin{tabular}{|c|c|c|c|c|c|c|}
\hline \multirow[b]{2}{*}{ Treatments } & \multicolumn{3}{|c|}{ 93-2144, susceptible } & \multicolumn{3}{|c|}{ 93-2098, resistant } \\
\hline & Root length & \% Loss & Top weight & Root length & \% Loss & Top weight \\
\hline No compaction, no $F$. solani & $22,690 \mathrm{a}$ & & 33.1 & $9,923 \mathrm{bcd}$ & & 38.6 \\
\hline Compaction, no $F$. solani & $13,750 \mathrm{~b}$ & 39.4 & 29.2 & $6,077 \mathrm{~d}$ & 38.8 & 35.9 \\
\hline No compaction, $F$. solani & $20,930 \mathrm{a}$ & 7.8 & 16.3 & $10,340 \mathrm{bc}$ & $\ldots$ & 15 \\
\hline Compaction, $F$. solani & $11,560 \mathrm{bc}$ & 49.1 & 13.8 & $7,948 \mathrm{~cd}$ & 20 & 14 \\
\hline $\mathrm{LSD}^{\mathrm{z}}$ & 2,746 & $\ldots$ & $\ldots$ & 2,746 & $\ldots$ & $\ldots$ \\
\hline
\end{tabular}

${ }^{\mathrm{y}}$ Root length measured in centimeters per plant and top weight measured in grams per plant. Numbers followed by the same letter are not significantly different at $P=0.05$.

${ }^{\mathrm{z}} \mathrm{LSD}=$ least significant difference. 


\section{LITERATURE CITED}

1. Allmaras, R. R., Kraft, J. M., and Miller, D. E. 1988. Effects of soil compaction and incorporated crop residue on root health. Annu. Rev. Phytopathol. 26:219-243.

2. Bennie, A. T. P. 1991. Growth and Mechanical Impedance. Pages 393-414 in: Plant Roots, the Hidden Half. Y. Eisel, A. Eshel, and U. Kafkafi, eds. Marcel Dekker, Inc., New York.

3. Burke, D. W., Holmes, L. D., and Barker, A. W. 1972. Distribution of Fusarium solani f. sp. phaseoli and bean roots in relation to tillage and soil compaction. Phytopathology 62:550-554.

4. Hagedorn, D. J., ed. 1984. Compendium of Pea Diseases. American Phytopathological Society, St. Paul, MN.

5. Heyes, J. K. 1977. Physiology of pea roots. Pages 153-181 in: The Physiology of the Garden Pea. J. F. Sutcliffe, and J. S. Pate, eds. Academic Press, London and New York.

6. Huisman, O. 1982. Interrelations of root growth dynamics to epidemiology of root invading fungi. Annu. Rev. Phytopathol.
20:303-327

7. Jungk, A. O. 1991. Dynamics of nutrient movement at the soil-root interface. Pages 455-481 in: Plant Roots: The Hidden Half. Y. Waisel, A. Eshel, and U. Kafkafi, eds. Marcel Dekker, Inc., New York.

8. Kraft. J. M., and Erwin, D. C. 1967. Stimulation of Pythium aphanidermatum by exudates from mung bean seeds. Phytopathology 57:866-868.

9. Kraft, J. M., and Kaiser, W. J., Jr. 1993. Screening for disease resistance in pea. Pages 123-144 in: Breeding for Stress tolerance in Cool-Season Food Legumes. K. B. Singh and M. C. Saxena, eds. John Wiley and Sons, New York.

10. Kraft, J. M., Marcinkowska, J., and Muehlbauer, F. J. 1990. Detection of Aphanomyces euteiches in field soil from northern Idaho by a wet-seiving/baiting technique. Plant Dis. 74:716-718.

11. Kraft, J. M., and Roberts, D. D. 1969. Influence of soil water and temperature on the pea root rot complex caused by Pythium ultimum and Fusarium solani f. sp. pisi. Phytopathol- ogy 59:149-152.

12. Kraft, J. M., and Wilkins, D. E. 1989. The effects of pathogen numbers and tillage on root disease asseverate, root length and seed yields in green peas. Plant Dis. 73:884-887.

13. Taylor, H. M., and Gardner, H. R. 1960. Relative penetrating ability of different plant roots. Agron. J. 52:579-581.

14. Torrey, J. G., and Zobel, R. 1977. Root Growth and Morphogenesis. Pages 119-152 in: The Physiology of the Garden Pea. J. F. Sutcliffe and J. S. Pate, eds. Academic Press, London and New York.

15. Waisel, Y., Eshel, A., and Kafkafi, U., eds. 1991. Plant Roots, the Hidden Half. Marcel Dekker, New York.

16. Ward, K. L., Klepper, B., Rickman, R. W., and Allmaras, R. R. 1978. Quantitative estimation of living wheat-root length in soil cores. Agron. J. 70:675-677.

17. Zobel. R. W. 1991. Genetic control of Root Systems. Pages 27-38 in: Plant Roots: The Hidden Half. Y. Waisel, A. Eshel, and U. Kafkafi, eds. Marcel Dekker, Inc. New York. 